\title{
Population dynamics, growth and predation impact of the common jellyfish Aurelia aurita and two hydromedusae, Sarsia tubulosa, and Aequorea vitrina in Limfjorden (Denmark)
}

\author{
Lene Friis Møller*, Hans Ulrik Riisgård
}

Marine Biological Research Centre, University of Southern Denmark, Hindsholmvej 11, 5300 Kerteminde, Denmark

\begin{abstract}
The population dynamics, growth and predation impact of the common jellyfish Aurelia aurita and 2 hydromedusae, Sarsia tubulosa and Aequorea vitrina, were studied in Limfjorden (Denmark), with the main focus on an inner branch of the fjord (Skive Fjord) from 2003 through 2005. We evaluated the degree to which the jellyfish realise their growth potential in Skive Fjord, and 2 other sites in Limfjorden (Nissum Bredning and Løgstør Bredning). We also evaluated whether the jellyfish were controlling the zooplankton, or if the biomass of zooplankton was controlling the growth of the jellyfish, by comparing prey concentrations in the sea with laboratory estimations of the minimum concentrations of prey needed for sustaining maximum growth of the jellyfish. In all 3 yr, A. aurita ephyrae and hydromedusae were present during spring, and in 2003 A. aurita was present through the entire study period (February to August). In April 2004, all jellyfish disappeared, but in August 2004 A. vitrina became abundant. In both 2004 and 2005, disappearance and reappearance of jellyfish coincided with sudden changes in the salinity caused by incoming water from the North Sea. By applying energy budgets from laboratory experiments, we calculated that the jellyfish realised their growth potential until August in 2003, after which negative growth was observed. In 2003, A. aurita in Skive Fjord had the potential to control the zooplankton from mid-May to August (half-life times between 0.8 and $6.2 \mathrm{~d}$ ). In this period, almost no zooplankton or fish larvae were present. Release of phytoplankton from zooplankton grazing-control due to the predation pressure (on zooplankton) from $A$. aurelia resulted in a pronounced phytoplankton bloom (with up to $60 \mu \mathrm{g} \mathrm{l}^{-1} \mathrm{chl}$ a in 2003) triggered by the release of nutrients from the sediment during a period of oxygen depletion in the nearbottom water. A. vitrina had no effect on the zooplankton population, but probably preyed on ctenophores. We conclude that in some years $A$. aurita may be very abundant in Limfjorden and might exert a considerable predatory impact on zooplankton and fish larvae during the summer. The abundance, species composition and population dynamics of jellyfish in Limfjorden may, at irregular time intervals, be strongly influenced by dramatic, but apparently rather unusual hydrographic events, and hydraulic processes may explain otherwise unaccountably large variations in the plankton (including jellyfish).
\end{abstract}

KEY WORDS: Predation impact - Control of growth · Plankton dynamics · Aurelia aurita Sarsia tubulosa $\cdot$ Aequorea vitrina

\section{INTRODUCTION}

Over the last 2 decades, the role of gelatinous predators in marine food-web and population dynamics has attracted growing scientific interest all over the world.
When jellyfish occur in large numbers, their predation impact may be so pronounced that they control the population sizes of prey organisms (Båmstedt 1990, Schneider \& Behrends 1994, Behrends \& Schneider 1995, Olesen 1995, Purcell 1997, Hansson et al. 2005). 
Thus, the common jellyfish Aurelia aurita was able to control the meso-zooplankton in Limfjorden, Denmark during the summer of 2003 (Hansson et al. 2005). When jellyfish are controlling the zooplankton, they may strongly compete with fish larvae and zooplanktivorous fish for food by eating the same prey items (Purcell \& Grover 1990). Both scyphozoan and hydrozoan jellyfish can feed on fish larvae. A. aurita was found to have a pronounced predation impact on the herring population in Kiel Bight, Germany (Möller 1984), and the hydromedusa Aequorea sp. caused high mortality on herring larvae in Kullet Bay, British Columbia (Purcell \& Grover 1990). It has been suggested that in the North Sea jellyfish have a negative impact on survival and recruitment of herring, probably by both direct predation and competition for food (Lynam et al. 2005).

Jellyfish seem well adapted to utilise favourable food opportunities, such as patches of zooplankton, and they can quickly increase predation and growth rates, causing rapid changes in the whole food-web structure (Båmstedt 1990). Nevertheless, jellyfish are often neglected in ecological studies, and little is known of their role in the energy flow of marine ecosystems.

The present study deals with population dynamics, growth and predation impact of Aurelia aurita and 2 hydromedusae Sarsia tubulosa and Aequorea vitrina (mainly in Skive Fjord, an inner branch of Limfjorden, Denmark) during the years 2003 to 2005. In this fjord, $S$. tubulosa is usually present in the plankton during early spring together with other hydromedusae and A. aurita ephyrae (Blanner 1982, Hansson et al. 2005). During summer, medusae of $A$. aurita may make up the the largest part of the plankton (Hansson et al. 2005). However, during August and September 2004, A. vitrina became very abundant, and concomitantly with this unusual event, the common jellyfish disappeared (Møller \& Riisgård 2007, this volume).

In a companion paper we examined the effects of temperature, medusa size, prey concentration and prey species on feeding and growth of species of jellyfish, and we constructed carbon budgets based on data from laboratory experiments in which feeding, growth and respiration were measured simultaneously (Møller \& Riisgård 2007). In the present work we use these findings to evaluate the degree to which Aurelia aurita, Sarsia tubulosa and Aequorea vitrina realise their growth potential in Limfjorden, and we evaluate whether these jellyfish may control the zooplankton community in this fjord, or conversely, whether the biomass of zooplankton may control the growth of the jellyfish. This was done by comparing natural prey concentrations in Limfjorden with previously determined minimum concentrations of prey needed for sustaining maximum growth of the jellyfish.

\section{MATERIALS AND METHODS}

Study area. The field work was conducted in the strongly eutrophicated Limfjorden, Denmark, a shallow fjord-system that is open to both the North Sea (32 to $34 \mathrm{psu}$ ) and to the Kattegat (19 to $25 \mathrm{psu}$ ). Limfjorden covers an area of $1500 \mathrm{~km}^{2}$ and has an average depth of $4.9 \mathrm{~m}$ (Fig. 1). The average salinity in the central part is $25 \mathrm{psu}$, and at the bottom it is usually a few psu higher than at the surface. During summer, a thermocline stabilizes this stratification, which can only be broken by strong winds. Large areas in the inner parts of the fjord (among these Skive Fjord) suffer each summer from oxygen depletion in the bottom waters, and this often results in release of toxic hydrogen sulphide from the sediments, causing mass mortality of the benthic fauna (Jørgensen 1980, Riisgård \& Poulsen 1981, Hoffmann \& Dolmer 2000).

Jellyfish population dynamics. In 2003, field sampling was carried out, in collaboration with the Danish Institute for Fisheries Research (Hansson et al. 2005), during 5 cruises at 12 stations around the western and middle part of Limfjorden. Collection of jellyfish for determination of size and abundance was the main objective, supplemented with sampling of fish eggs and larvae.

Oblique hauls were made through the water column to get the average abundance of jellyfish. A $500 \mu \mathrm{m}$ mesh Bongo net $\left(0.29 \mathrm{~m}^{2}\right.$ mouth area) was used for sampling hydromedusae and ephyra larvae, while a $2 \mathrm{~mm}$ plankton net $\left(1.77 \mathrm{~m}^{2}\right.$ mouth area) was used for large medusae. Fish eggs and larvae were caught by Bongo net hauls towed obliquely between near sea bed and surface, and the samples were preserved in formalin for subsequent counting and measurement in the laboratory. The larger medusae were counted on ship, and their umbrella diameters were measured. During the first 4 cruises (24 to 27 February, 8 to

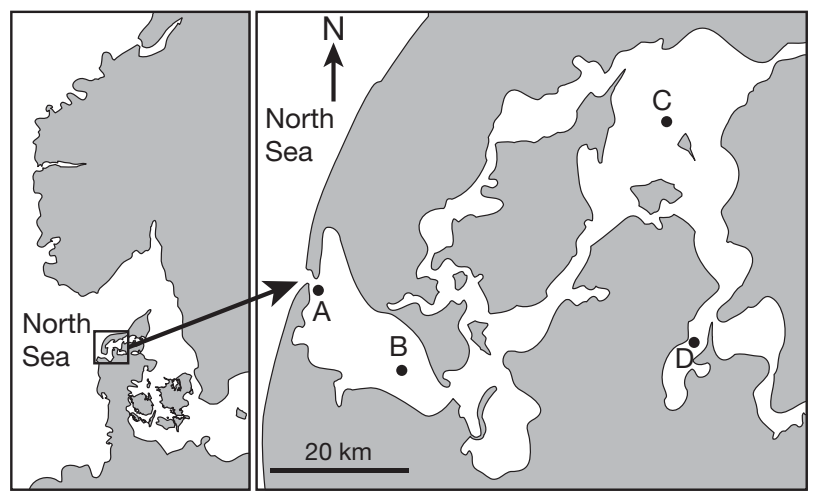

Fig. 1. Jellyfish sampling locations (A-D) in Limfjorden, Denmark. A: Thyborøn Kanal 56 $42^{\prime} \mathrm{N}-8^{\circ} 14^{\prime} \mathrm{E}$; B: Nissum Bredning $56^{\circ} 36^{\prime} \mathrm{N}-8^{\circ} 27^{\prime} \mathrm{E}$; C: Løgstør Bredning $56^{\circ} 59^{\prime} \mathrm{N}-9^{\circ} 03^{\prime} \mathrm{E}$; D: Skive Fjord $56^{\circ} 39^{\prime} \mathrm{N}-9^{\circ} 07^{\prime} \mathrm{E}$ 
11 April, 20 to 24 May, 1 to 4 July) samples were taken of both types of jellyfish, fish eggs and larvae at all stations, but on the last cruise (26 to 27 August) only large scyphozoan jellyfish were collected (for further details, see Hansson et al. 2005).

In order to get information more detailed than that obtained in 2003, a sampling programme for 2004 and 2005 was conducted in Skive Fjord (Fig. 1) in cooperation with the Limfjord County Authorities (Limfjordsamterne). Skive Fjord is one of the locations in the Danish national monitoring program (Svendsen \& Norup 2005), and as part of the weekly sampling programme, jellyfish were collected from February to October in 2004 and 2005. A plankton net $\left(0.20 \mathrm{~m}^{2}\right.$ mouth area) with a mesh size of $500 \mu \mathrm{m}$ was used for collecting hydromedusae. The samples were preserved in Lugol's solution and sent to the laboratory to be identified, measured and counted. In 2004, the $500 \mu \mathrm{m}$ mesh net was used from February to June, and a $2 \mathrm{~mm}$ mesh net was used from June to October for collecting larger medusae. In 2005, the $500 \mu \mathrm{m}$ and $2 \mathrm{~mm}$ nets were used from February to September, and from September to October, respectively. One and 3 hauls were made with the $2 \mathrm{~mm}$ net on each sampling day in 2004 and 2005, respectively, whereas 4 and 3 hauls per day were made with the $500 \mu \mathrm{m}$ net in 2004 and 2005, respectively. The abundances of dominating hydromedusae and Aurelia aurita were estimated, and medusa height (Sarsia tubulosa) or diameter (Aurelia aurita and Aequorea vitrina) were measured on all individuals in every haul, and in no case were fewer than 10 ind. measured.

The following data from Skive Fjord for 2003 to 2005 were obtained from the Limfjord County Authorities' monitoring program: temperature, oxygen, nutrients, primary production, chl $a$, and zooplankton composition and concentration (including fish eggs and larvae). Zooplankton data were likewise obtained for Nissum Bredning and Løgstør Bredning in 2003 (for sampling details, see Andersen et al. 2004).

Bioenergetics. For Aurelia aurita, Sarsia tubulosa and Aequorea vitrina, specific growth rates $\left(\mu, \mathrm{d}^{-1}\right)$ in the field were calculated as: $\mu=\ln \left(W_{\mathrm{C}, t} / W_{\mathrm{C}, 0}\right) / t$, where $W_{\mathrm{C}, t}$ and $W_{\mathrm{C}, 0}=$ mean individual carbon content on Day 0 and Day $t$, respectively. $\mu$ was calculated for individuals collected on 2 sampling dates 1 wk apart, but only if the salinity profiles measured on the 2 sampling dates were similar, indicating that the individuals were sampled from the same water mass, and thus the same population.

The theoretical half-life time of prey organisms was calculated as $t_{1 / 2}=\ln 2 / Q$, where $Q=F \times N=$ clearance rate of jellyfish population $\mathrm{m}^{-3}$ water, where $F=$ individual clearance and $N=$ density of jellyfish $\mathrm{m}^{-3}$, assuming $F$ to be constant, regardless of prey concen- tration. $F\left(\mathrm{l} \mathrm{d}^{-1}\right)$ was calculated for a medusa of a given body mass ( $W$, mg dry wt) at a given temperature from the following relations (Møller \& Riisgård 2007): Aurelia aurita preying on copepods (Acartia tonsa): $F=$ $0.76 W^{0.73}$ ( $D=5$ to $65 \mathrm{~mm}$ ); Aequorea vitrina preying on copepods (Acartia tonsa): $F=0.1 W^{0.91}(D=6$ to $50 \mathrm{~mm})$. For both medusa species, temperature correction was made using: $F=1.17 \mathrm{e}^{0.18 T}$, where $T=$ temperature $\left({ }^{\circ} \mathrm{C}\right)$. For Pleurobrachia pileus preying on copepods, we used the following expression: $F=0.01 D^{3.22}$, where $D=$ body diameter (Gibbons \& Painting 1992). We assumed that the relations between individual sizes and clearance rates used in the present study were also valid for medusae larger than those used in the clearance experiments.

Maximum specific growth rates, $\mu_{\max }$, were calculated for a given medusa size at a given temperature (Møller \& Riisgård 2007). For Aurelia aurita ephyrae and Sarsia tubulosa, maximum specific growth rates of 0.24 and $0.32 \mathrm{~d}^{-1}\left(15^{\circ} \mathrm{C}\right)$ were used, while calculations from $\mu_{\max }=0.34 W_{0}^{-0.28}\left(W_{0}=90\right.$ to $\left.1900 \mathrm{mg}\right)$ were used for $A$. aurita medusae and $\mu_{\max }=0.17 W_{0}^{-0.34}\left(W_{0}=2\right.$ to $50 \mathrm{mg}$ ) for Aequorea vitrina, where $W_{0}=$ dry weight on Day 0. Temperature corrections were made from the following relations: $\mu=0.0081 \mathrm{e}^{0.18 T}$ (ephyrae and Sarsia tubulosa), and $\mu=0.0032 \mathrm{e}^{0.14 T}$ for $A$. aurita medusae and $A$. vitrina, respectively, where $T$ is the average temperature between Day 0 and Day $t$ (Møller \& Riisgård 2007).

Conversion factors. The following equations were used to estimate body dry weight ( $W, \mathrm{mg})$ from umbrella diameter $(D, \mathrm{~mm})$ for Aurelia aurita: ephyrae: $W=1.913 \times 10^{-3} D^{2.998}$ (Båmstedt et al. 1999); medusae $(\geq 20 \mathrm{~mm}): W=0.004 D^{2.7}$ (Møller \& Riisgård 2007); and for Aequorea vitrina: $W=0.03 D^{2.3}$ (Møller \& Riisgård 2007). For Sarsia tubulosa, the bell height $(H, \mathrm{~mm})$ was converted to carbon content $\left(W_{\mathrm{C}}, \mu \mathrm{g} \mathrm{C}\right)$ : $W_{\mathrm{C}}=0.443 H^{3.10}$ (Daan 1986). $1 \mathrm{mg}$ dry wt (ephyra) $=$ $3.66 \mathrm{~J}=70 \mu \mathrm{g} \mathrm{C}_{i} 1 \mathrm{mg}$ dry wt (medusae) $=50 \mu \mathrm{g} \mathrm{C}$ (Schneider 1988).

\section{RESULTS}

\section{Jellyfish dynamics}

The abundances of the dominating hydromedusae and Aurelia aurita in Skive Fjord in 2004 are shown in Fig. 2. From mid February to April, Sarsia tubulosa and A. aurita ephyrae were the most abundant species with densities of up to 2.5 and 5 ind. $\mathrm{m}^{-3}$, respectively. There was a marked change in the abundance of jellyfish in the period between 29 March and 5 April. From 5 April to 23 August, the abundance was low with only Obelia spp. appearing in quantifiable amounts. During 


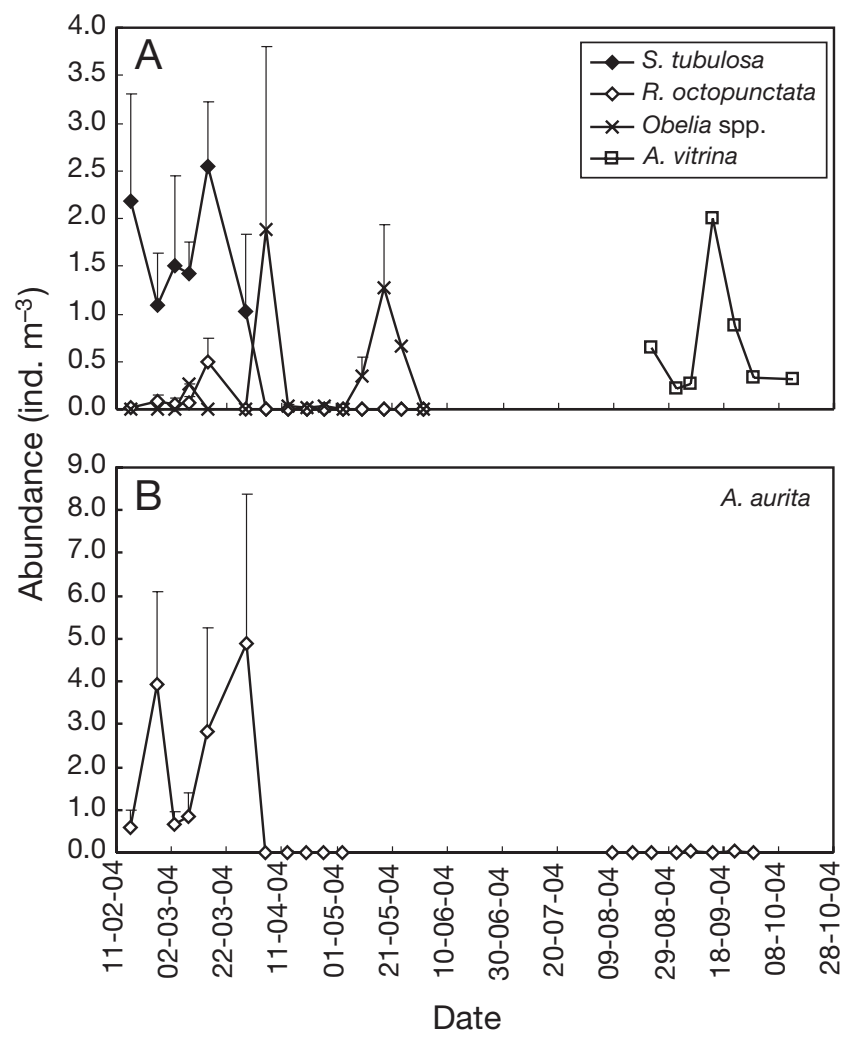

Fig. 2. Abundance (mean $+\mathrm{SD}$ ) of $(\mathrm{A})$ dominant hydromedusae (Sarsia tubulosa, Rathkea octopunctata, Obelia spp., Aequorea vitrina) and (B) Aurelia aurita in Skive Fjord in 2004 (dates are dd-mm-yy)

summer, no sampling was made for small hydromedusae. From 23 August to mid October, the hydromedusa Aequorea vitrina, which had not been recorded previously in Limfjorden, became very abundant (up to 2 ind. $\mathrm{m}^{-3}$ ). Also, $A$. aurita reappeared. The drastic changes in jellyfish abundances in spring coincided with conspicuous changes in the salinity profile (Fig. 3A). Clearly, new highly saline and denser seawater gradually forced the older, less dense waster masses out of Skive Fjord. Likewise in August, new highly saline water forced out the older more brackish water in Skive Fjord, and this time, the old 21.8 psu surface water (9 August) was completely replaced with 27 psu seawater in mid September, when no stratification was observed (Fig. 3B) and A. vitrina was seen for the first time. This indicates that $A$. vitrina was introduced into the Limfjord with highly saline North Sea water entering the fjord system from the west through the Thyborøn Kanal, assisted by exceptionally strong westerly winds.

In 2005 the hydromedusae, especially Sarsia tubulosa, and Aurelia aurita ephyrae, were abundant during early spring (Fig. 4). On 15 March both ephyrae, S. tubulosa and Rathkea octopunctata were abundant,

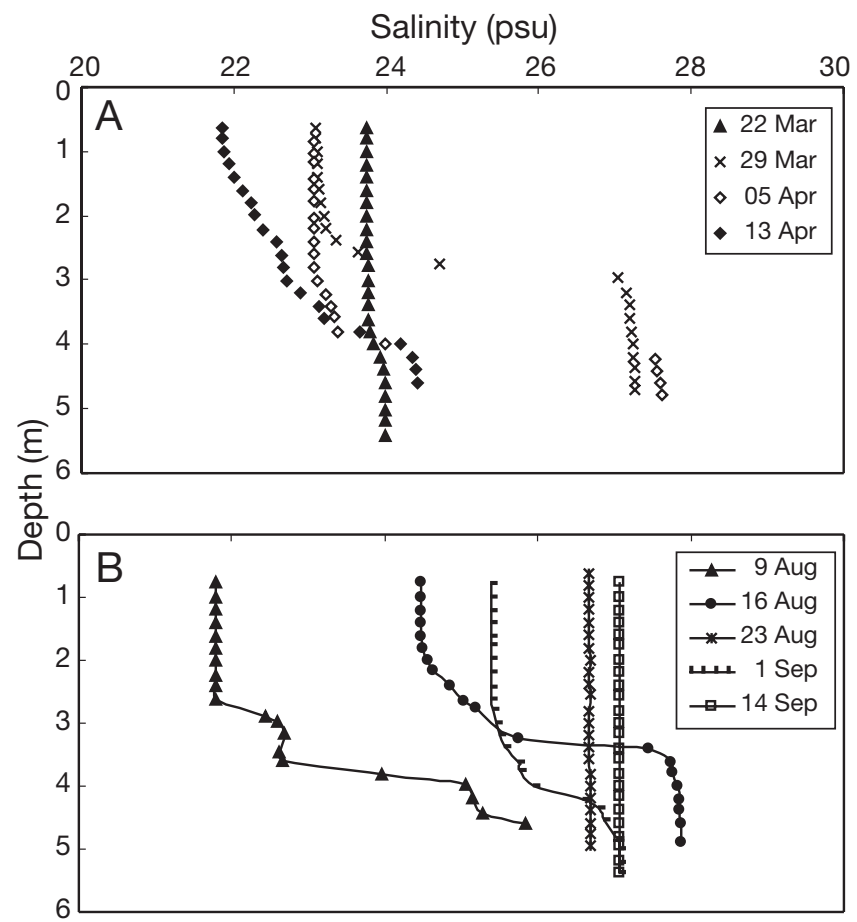

Fig. 3. Salinity profiles in (A) spring and (B) autumn in Skive Fjord in 2004

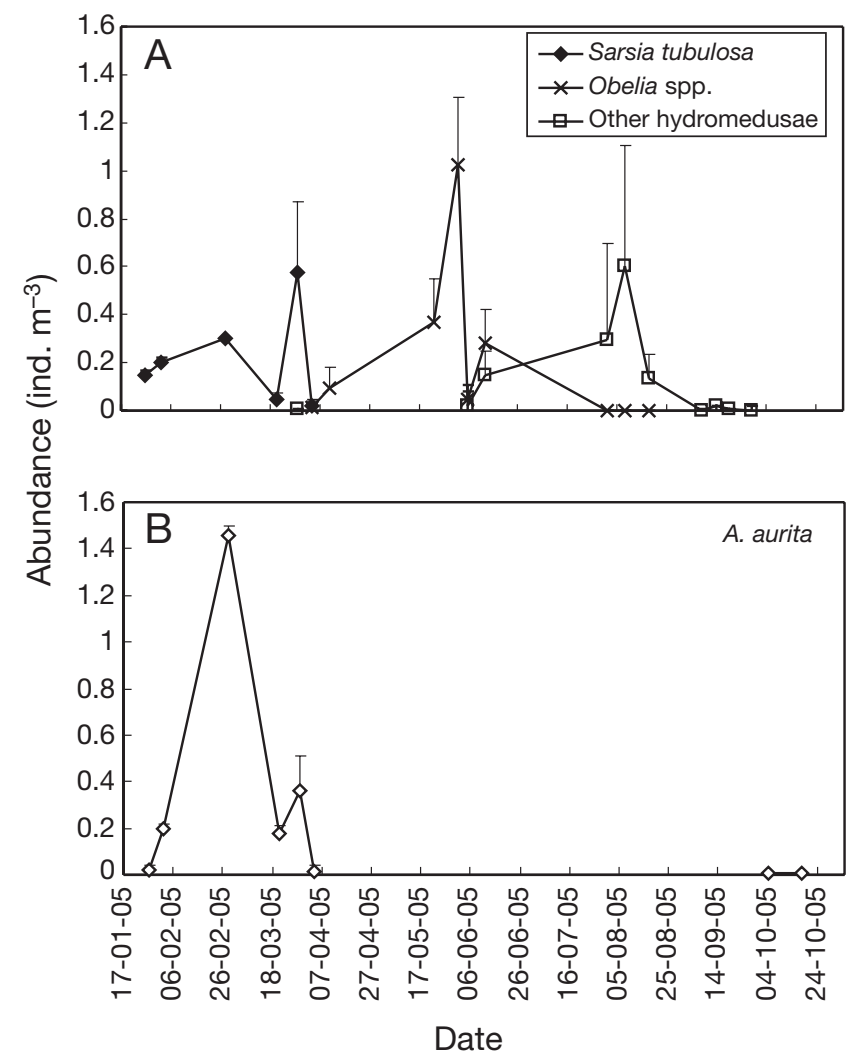

Fig. 4. Abundance (mean $+\mathrm{SD}$ ) of $(\mathrm{A})$ dominant hydromedusae and (B) Aurelia aurita in Skive Fjord in 2005 (dates are dd-mm-yy) 
but due to an algal bloom it was impossible to count the numbers in the samples. In general, the abundances were lower than in 2004 (maximum 0.4 ind. $\mathrm{m}^{-3}$ for $S$. tubulosa and 1.4 for ephyrae). During the 2 sampling dates, 4 April and 11 April, all jellyfish disappeared and, as in 2004, this occurred concurrently with pronounced changes in salinity. Since the $500 \mu \mathrm{m}$ net was used during summer, hydromedusae were also recorded. During spring/summer Obelia spp. reappeared, and after June, other hydromedusae, especially Sarsia gemmifera and Leuckartiara octona, also occurred. In August a few large A. aurita and Aequorea vitrina occurred, but at very low densities, with maxima of 0.01 and 0.04 ind. $\mathrm{m}^{-3}$, respectively.

Monitoring of the abundance of ctenophores Pleurobrachia sp. was not a regular part of the programme. However, during the cruises on 23 August and 22 September, a marked change in abundance was noted. On 23 August the net filled up with Pleurobrachia sp., while only few were present on 22 September. In 2005, Pleurobrachia sp. was present in such high densities that it clogged the net from the beginning of August to the end of September. Ctenophores are difficult to preserve and they easily break, but intact individuals were counted in the preserved samples. The abundances of individuals of about $1 \mathrm{~cm}$ diameter was 0.5 to 1 ind. $\mathrm{m}^{-3}$ during August and September, but this number is an underestimate since many damaged individuals were seen in the samples, and they were not counted.

\section{Growth and predation impact of jellyfish}

The measured umbrella diameters and estimated actual specific growth rates $\left(\mu_{\mathrm{act}}\right)$ for Aurelia aurita col- lected at different localities in Limfjorden in 2003 are shown in Table 1. In general, the specific growth rate was relatively low in April $\left(0.05 \mathrm{~d}^{-1}\right)$, maximum in May $\left(0.15\right.$ to $\left.0.17 \mathrm{~d}^{-1}\right)$, followed by a reduction in July $(0.02$ to $\left.0.11 \mathrm{~d}^{-1}\right)$, and finally specific growth rate was negative in August ( -0.03 to $\left.0 \mathrm{~d}^{-1}\right)$.

The actual specific growth rates $\left(\mu_{\mathrm{act}}\right)$ for Aurelia aurita in Skive Fjord, Nissum Bredning and Løgstør Bredning in 2003 are shown in Table 2, together with the estimated maximum specific growth rates $\left(\mu_{\max }\right)$ (calculated on basis of laboratory experiments), and the estimated half-life times $\left(t_{1 / 2}\right)$ of copepods (Acartia tonsa). Since $\mu_{\mathrm{act}}$ conformed to $\mu_{\max }$ in most cases, we conclude that the growth potential of the jellyfish was usually realised until August, when the actual growth became lower than the estimated growth (production). In Skive Fjord, the half-life times were low during summer, viz. 6.2, 3.2 and $0.8 \mathrm{~d}$ in May, July and August, respectively. In Nissum Bredning, the $t_{1 / 2}$-value was relatively low $(12.1 \mathrm{~d})$ around the beginning of July, but during the rest of the summer, the half-life times were higher than $30 \mathrm{~d}$. In Løgstør Bredning, $t_{1 / 2}$-values were $26 \mathrm{~d}$ at the end of May, after which the half-life times became relatively low, viz. 6.1 and $11.1 \mathrm{~d}$ in July and August, respectively.

In Table 3 the actual specific growth rates for Aurelia aurita ephyrae and Sarsia tubulosa are shown for spring 2004 and 2005. The specific growth rates varied between 0 and 0.12 for ephyrae and -0.07 and 0.16 for $S$. tubulosa. For comparison, the calculated maximum specific growth rate was about $0.05 \mathrm{~d}^{-1}$ for both A. aurita ephyrae and $S$. tubulosa.

In August 2004, Aurelia aurita reoccurred and its specific growth rate was $0.05 \mathrm{~d}^{-1}$, but after that there was a tendency towards negative growth (Table 4). Half-life times for copepods were $>37 \mathrm{~d}$.

Table 1. Aurelia aurita. $D$ : umbrella diameter (mean $\pm \mathrm{SD}$ ); $\mu_{\text {act }}$ : actual specific growth rate at various sampling stations in Limfjorden in 2003. (Data and stations are from Hansson et al. 2005, see their Fig. 1. No data were available for Thyborøn)

\begin{tabular}{|c|c|c|c|c|c|c|c|c|c|}
\hline \multirow[t]{2}{*}{ Station/Locality } & \multicolumn{5}{|c|}{$-D(\mathrm{~mm})$} & \multicolumn{4}{|c|}{$-\mu_{\text {act }}\left(\mathrm{d}^{-1}\right)-$} \\
\hline & $24-27$ & 8-11 & $20-24$ & $1-4$ & 26-27 & 8-11 & $20-24$ & $1-4$ & $26-27$ \\
\hline \multicolumn{10}{|l|}{ A Thyborøn } \\
\hline B Nissum Bredning & $4.3 \pm 0.8$ & $8.0 \pm 3.0$ & & $192 \pm 20$ & $141 \pm 29$ & 0.05 & & 0.11 & -0.02 \\
\hline C Venø & & & $104 \pm 44$ & $219 \pm 44$ & & & & 0.05 & \\
\hline D Nykøbing-Kås Bredning & & & $127 \pm 47$ & & & & & & \\
\hline E Visby Bredning & & & & $223 \pm 33$ & $129 \pm 35$ & & & & -0.03 \\
\hline F Thisted Bredning & & & $125 \pm 28$ & $164 \pm 34$ & $106 \pm 36$ & & & 0.02 & -0.02 \\
\hline G Løgstør Bredning & $3.6 \pm 3.9$ & $7.7 \pm 2.7$ & $111 \pm 20$ & $147 \pm 28$ & $122 \pm 34$ & 0.05 & 0.17 & 0.02 & -0.01 \\
\hline H Løgstør Kanal & & & $107 \pm 30$ & $154 \pm 31$ & & & & 0.03 & \\
\hline I Øst Livø Bredning & & & & $149 \pm 30$ & & & & & \\
\hline J Risgårde Bredning & & & $98 \pm 31$ & $132 \pm 23$ & $129 \pm 28$ & & & 0.02 & 0.00 \\
\hline K Skive Fjord & & $7.1 \pm 2.7$ & $65 \pm 24$ & $141 \pm 22$ & $136 \pm 29$ & & 0.15 & 0.05 & 0.00 \\
\hline L Lovns Bredning & & & $63 \pm 25$ & $142 \pm 23$ & $155 \pm 37$ & & & 0.06 & 0.00 \\
\hline
\end{tabular}


Table 2. Aurelia aurita. Data from 3 localities in 2003 (Fig. 1): Skive Fjord (S), Nissum Bredning $(\mathrm{N})$ and Løgstør Bredning $(\mathrm{L})$. $W_{\mathrm{C}}$ : mean individual $( \pm \mathrm{SD})$ carbon content of medusae; $N$ : abundance; $\mu_{\text {act }}$ : actual specific growth rate; $\mu_{\max }$ : estimated maximum specific growth rate; $t_{1 / 2}$ : half-life time for Acartia tonsa. $\infty$ indicates $t_{1 / 2}>30 \mathrm{~d}$

\begin{tabular}{|lcrccccc|}
\hline Date & Locality & $\begin{array}{c}\text { Temp. } \\
\left({ }^{\circ} \mathrm{C}\right)\end{array}$ & $\begin{array}{c}W_{\mathrm{C}} \\
(\mathrm{mg} \mathrm{C})\end{array}$ & $\begin{array}{c}N \\
\left(\text { ind. } \mathrm{m}^{-3}\right)\end{array}$ & $\begin{array}{r}\mu_{\text {act }} \\
\left(\mathrm{d}^{-1}\right)\end{array}$ & $\begin{array}{c}\mu_{\max } \\
\left(\mathrm{d}^{-1}\right)\end{array}$ & $\begin{array}{c}t_{1 / 2} \\
(\mathrm{~d})\end{array}$ \\
\hline 09 April 03 & $\mathrm{S}$ & 5 & $0.1 \pm 0.0$ & 11 & & & $\infty$ \\
20 May 03 & $\mathrm{S}$ & 12 & $15.7 \pm 1.1$ & 3.7 & 0.15 & 0.15 & 6.2 \\
01 July 03 & $\mathrm{S}$ & 18 & $126.4 \pm 0.8$ & 0.6 & 0.05 & 0.07 & 3.2 \\
26 August 03 & $\mathrm{S}$ & 18 & $115.6 \pm 2.1$ & 2.4 & 0 & 0.07 & 0.8 \\
09 April 03 & $\mathrm{N}$ & 6 & $0.1 \pm 0.0$ & 0.04 & 0.05 & 0.04 & $\infty$ \\
20 May 03 & $\mathrm{N}$ & 11 & & 0 & & & $\infty$ \\
01 July 03 & $\mathrm{N}$ & 17 & $293.0 \pm 0.7$ & 0.08 & 0.11 & 0.18 & 12.1 \\
26 August 03 & $\mathrm{N}$ & 18 & $127.0 \pm 1.8$ & 0.01 & -0.02 & 0.05 & $\infty$ \\
09 April 03 & $\mathrm{L}$ & 6 & $0.1 \pm 0.0$ & & 0.05 & 0.04 & \\
20 May 03 & $\mathrm{L}$ & 12 & $66.6 \pm 0.7$ & 0.7 & 0.17 & 0.14 & 25.7 \\
01 July 03 & $\mathrm{L}$ & 18 & $142.2 \pm 1.6$ & 0.5 & 0.02 & 0.04 & 6.1 \\
26 August 03 & $\mathrm{L}$ & 18 & $86.0 \pm 2.7$ & 0.3 & -0.09 & 0.07 & 11.1 \\
\hline
\end{tabular}

\section{Plankton dynamics}

Data on oxygen, nutrients, primary production, chl $a$, and zooplankton in Skive Fjord in 2003, 2004 and 2005 are shown in Fig. 5. Oxygen deficiency occurred every summer, causing nutrient (phosphate and ammonium) release from the sediment in August, and this subsequently triggered a peak in the primary production. In 2003, this event resulted in a phytoplankton bloom with extremely high chl a concentrations (up to $60 \mathrm{\mu g} \mathrm{l}^{-1}$ ) in the surface water. In both 2004 and 2005, the phytoplankton blooms were considerably smaller, at

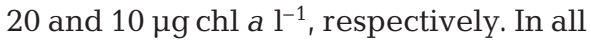
$3 \mathrm{yr}$, the meso-zooplankton responded to the phytoplankton bloom by increasing its biomass.

Specific growth rates for Aequorea vitrina in Skive Fjord 2004 are listed in Table 5. During the period 23 August to 6 September, $\mu_{\max }$, was about $0.04 \mathrm{~d}^{-1}$. For comparison, the estimated maximum specific growth rate (for the observed sizes of animals at the temperature measured) was 0.02 to $0.05 \mathrm{~d}^{-1}$, which indicates that the growth potential was realised. Half-life times calculated for copepods were $>54 \mathrm{~d}$. Due to changes in hydrography in the period 6 to 14 September (not shown), we were probably not sampling individuals from the same populations of $A$. aurita and $A$. vitrina, as can also be seen from the large variations in size and abundance of $A$. vitrina in this period.

Predation impact $\left(t_{1 / 2}\right)$ of Pleurobrachia sp. was estimated to be approximately $25 \mathrm{~d}$ in August and September. However, the actual predation impact was certainly higher since the abundance of Pleurobrachia sp. was underestimated.

Table 3. Aurelia aurita and Sarsia tubulosa. Mean $( \pm \mathrm{SD})$ individual biomass $\left(W_{\mathrm{C}}\right)$ and actual specific growth rate $\left(\mu_{\mathrm{act}}\right)$ of $A$. aurita ephyrae and $S$. tubulosa in Skive Fjord during spring 2004 and 2005

\begin{tabular}{|c|c|c|c|c|c|}
\hline \multirow[t]{2}{*}{ Date } & \multirow{2}{*}{$\begin{array}{c}\text { Temp. } \\
\left({ }^{\circ} \mathrm{C}\right)\end{array}$} & \multicolumn{2}{|c|}{$-W_{\mathrm{C}}(\mu \mathrm{g} \mathrm{C})-$} & \multicolumn{2}{|c|}{$-\mu_{\mathrm{act}}\left(\mathrm{d}^{-1}\right)$} \\
\hline & & Ephyrae & Sarsia & Ephyrae & Sarsia \\
\hline 16 February 04 & 1.6 & $1.3 \pm 0.0$ & 0.3 & & \\
\hline 26 February 04 & 1.6 & $2.5 \pm 0.1$ & 1.6 & 0.06 & 0.16 \\
\hline 03 March 04 & 2.4 & $4.5 \pm 0.2$ & 0.8 & 0.12 & -0.07 \\
\hline 08 March 04 & 1.7 & $4.5 \pm 0.2$ & 0.8 & 0.00 & 0.00 \\
\hline 15 March 04 & 2.7 & $4.5 \pm 0.5$ & 3.3 & 0.00 & 0.14 \\
\hline 29 March 04 & 5.2 & $10.8 \pm 0.1$ & 7.6 & 0.08 & 0.06 \\
\hline 02 February 05 & 2.5 & $0.5 \pm 0.0$ & 0.2 & & 0.06 \\
\hline 28 February 05 & -0.9 & 0 & 0.3 & & 0.02 \\
\hline 21 March 05 & 2.5 & $9.9 \pm 0.2$ & 1.0 & 0.07 & 0.05 \\
\hline 29 March 05 & 5.7 & $13.7 \pm 0.5$ & 1.3 & 0.04 & 0.03 \\
\hline
\end{tabular}

Fig. 6 shows the species composition of the most abundant meso-zooplankton species in Skive Fjord. The peak biomass of meso-zooplankton in mid August appearing in response to the phytoplankton bloom consisted mainly of nauplii $\left(200 \mu \mathrm{g} \mathrm{C} \mathrm{l}^{-1}\right)$ in 2003,

Table 4. Aurelia aurita in Skive Fjord 2004. $W_{\mathrm{C}}$ : mean individual $( \pm \mathrm{SD})$ carbon content of medusae; $N$ : abundance; $\mu_{\text {act }}$ : actual specific growth rate

\begin{tabular}{|lccrr|}
\hline Date & $\begin{array}{c}\text { Temp. } \\
\left({ }^{\circ} \mathrm{C}\right)\end{array}$ & $\begin{array}{c}W_{\mathrm{C}} \\
(\mathrm{mg} \mathrm{C})\end{array}$ & $\begin{array}{c}N \\
\left(\text { ind. } \mathrm{m}^{-3}\right)\end{array}$ & $\begin{array}{r}\mu_{\text {act }} \\
\left(\mathrm{d}^{-1}\right)\end{array}$ \\
\hline 09 August 04 & 21.5 & & 0.01 & \\
23 August 04 & 17.7 & $702 \pm 5$ & 0.01 & 0.05 \\
01 September 04 & 17.2 & $546 \pm 4$ & 0.02 & -0.04 \\
06 September 04 & 17.6 & $344 \pm 2$ & 0.02 & -0.09 \\
14 September 04 & 16.5 & $334 \pm 1$ & 0.01 & 0.00 \\
22 September 04 & 14.3 & $189 \pm 27$ & 0.04 & -0.07 \\
29 September 04 & 13.6 & $184 \pm 1$ & 0.02 & 0.00 \\
\hline
\end{tabular}

Table 5. Aequorea vitrina in Skive Fjord 2004. W: mean individual $( \pm \mathrm{SD})$ dry weight of medusae; $N$ : abundance; $\mu_{\text {act }}$ : actual specific growth rate

\begin{tabular}{|lrcc|}
\hline Date & $W(\mathrm{mg})$ & $N\left(\right.$ ind. $\left.\mathrm{m}^{-3}\right)$ & $\mu_{\text {act }}\left(\mathrm{d}^{-1}\right)$ \\
\hline 23 August 04 & $167 \pm 16$ & 0.6 & \\
01 September 04 & $259 \pm 27$ & 0.2 & 0.05 \\
06 September 04 & $283 \pm 40$ & 0.3 & 0.02 \\
14 September 04 & $98 \pm 25$ & 2.0 & \\
22 September 04 & $148 \pm 11$ & 0.9 & 0.05 \\
29 September 04 & $143 \pm 31$ & 0.3 & 0.00 \\
13 October 04 & $105 \pm 8$ & 0.3 & -0.02 \\
\hline
\end{tabular}



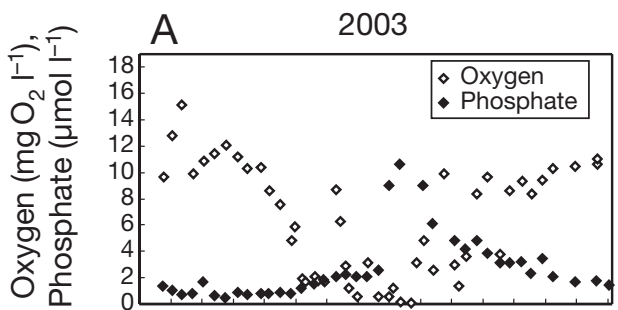

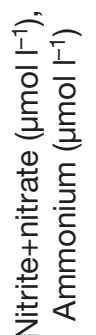

B
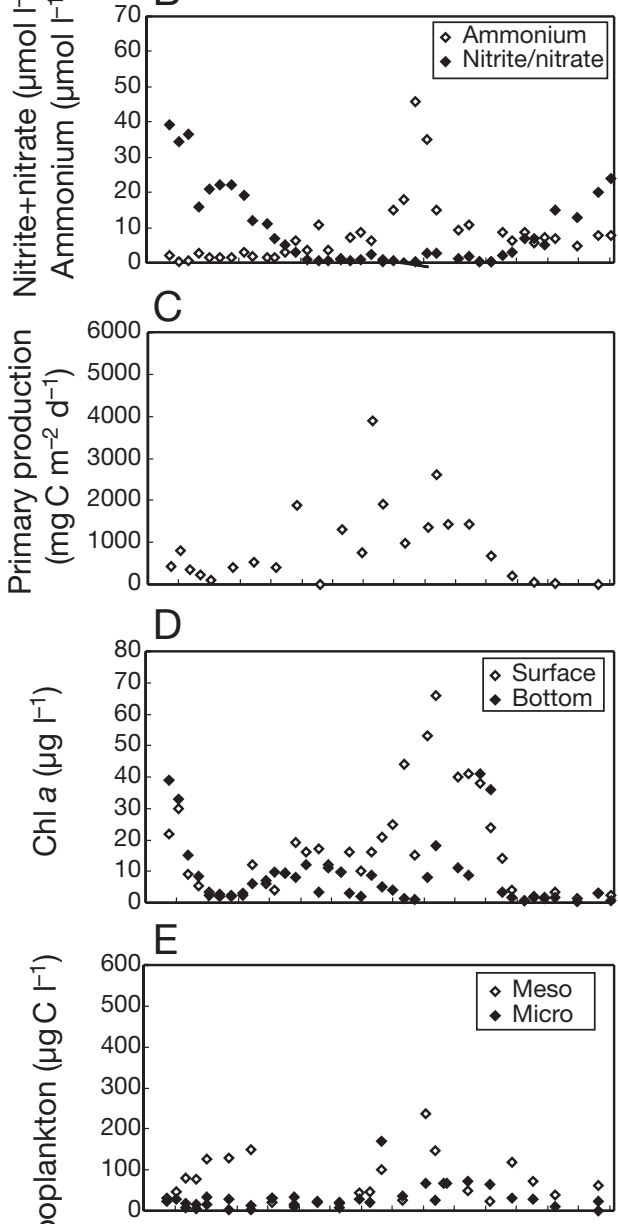

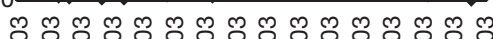
ヘิ่

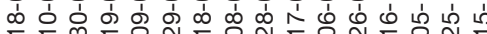
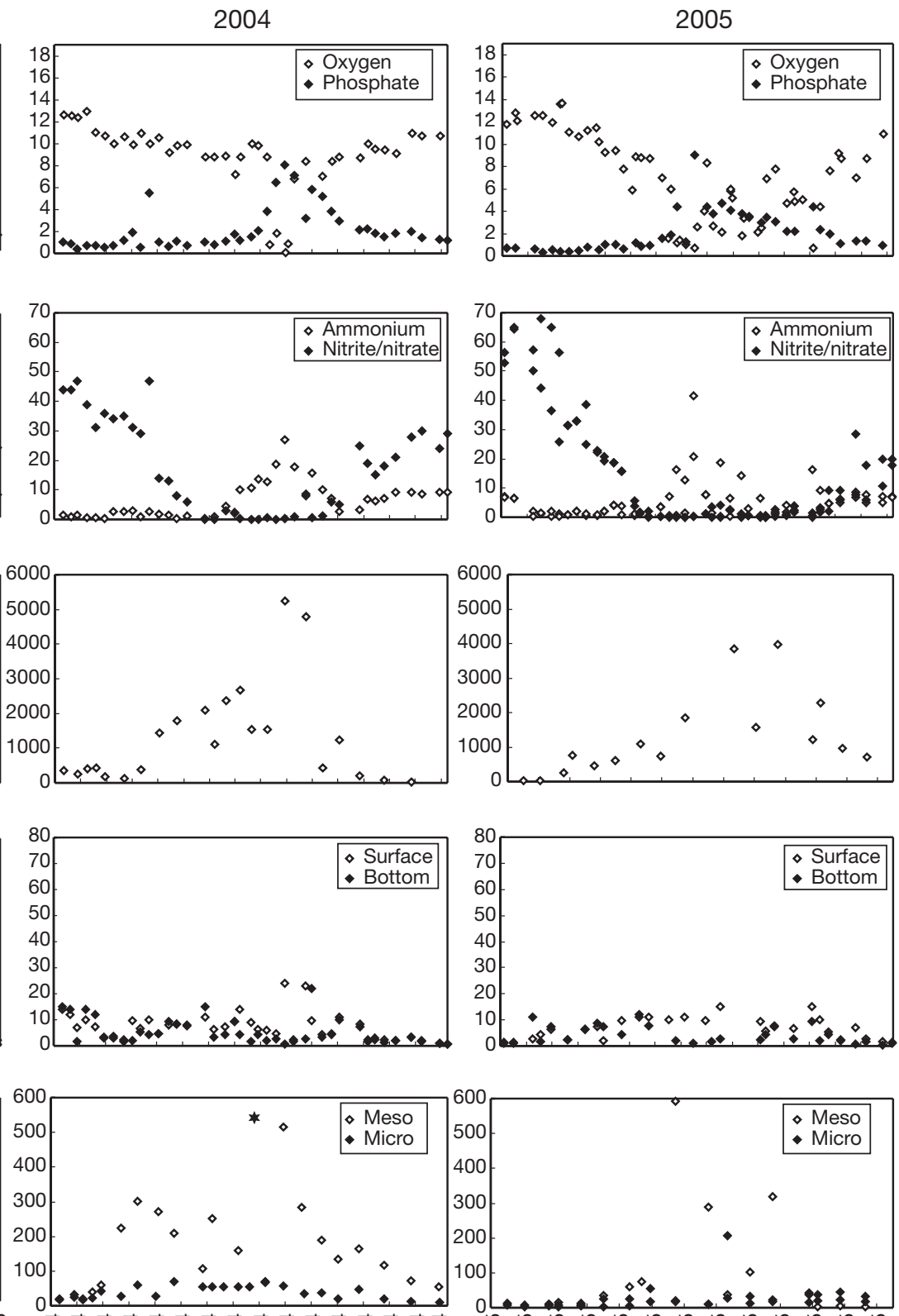

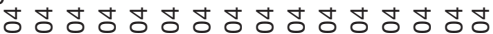

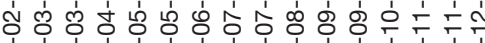

文

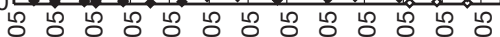
ヘิ่

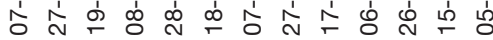

Date

Fig. 5. Skive Fjord: Physico/chemical factors in 2003, 2004, and 2005. (A) Oxygen and phosphate concentration in bottom water; (B) ammonium and nitrate + nitrite concentration in bottom water; (C) primary production; (D) chl a concentration in surface and bottom water; (E) total biomass of micro- and meso-zooplankton, * indicates a total biomass of $1300 \mu \mathrm{g} \mathrm{C} \mathrm{l}^{-1}$ (mainly polychaete larvae) (dates are dd-mm-yy)

mostly copepods and some nauplii $\left(500 \mu \mathrm{g} \mathrm{C}^{-1}\right)$ in 2004, and mostly nauplii and some copepods $\left(300 \mathrm{\mu g} \mathrm{C} \mathrm{l}^{-1}\right)$ in 2005. In 2003, almost no zooplankton was present from mid May to the beginning of July. During July, zooplankton (mainly copepods, up to $120 \mu \mathrm{g} \mathrm{C} \mathrm{l}^{-1}$ ) was present. In 2004 zooplankton was present all summer (250 to $300 \mu \mathrm{g} \mathrm{C}^{-1}$ ), mainly copepods and cladocerans. But polychaete larvae were also very abundant, and peaked in late July at $1300 \mu \mathrm{g} \mathrm{C} \mathrm{l}^{-1}$. In 2005, cladocerans were the dominant species from mid May to July, with concentrations up to $550 \mu \mathrm{g} \mathrm{C} \mathrm{l}^{-1}$. The species composition during spring consisted mainly of copepods in 2003, while in 2004 and 2005 cirriped and polychaete larvae dominated. 

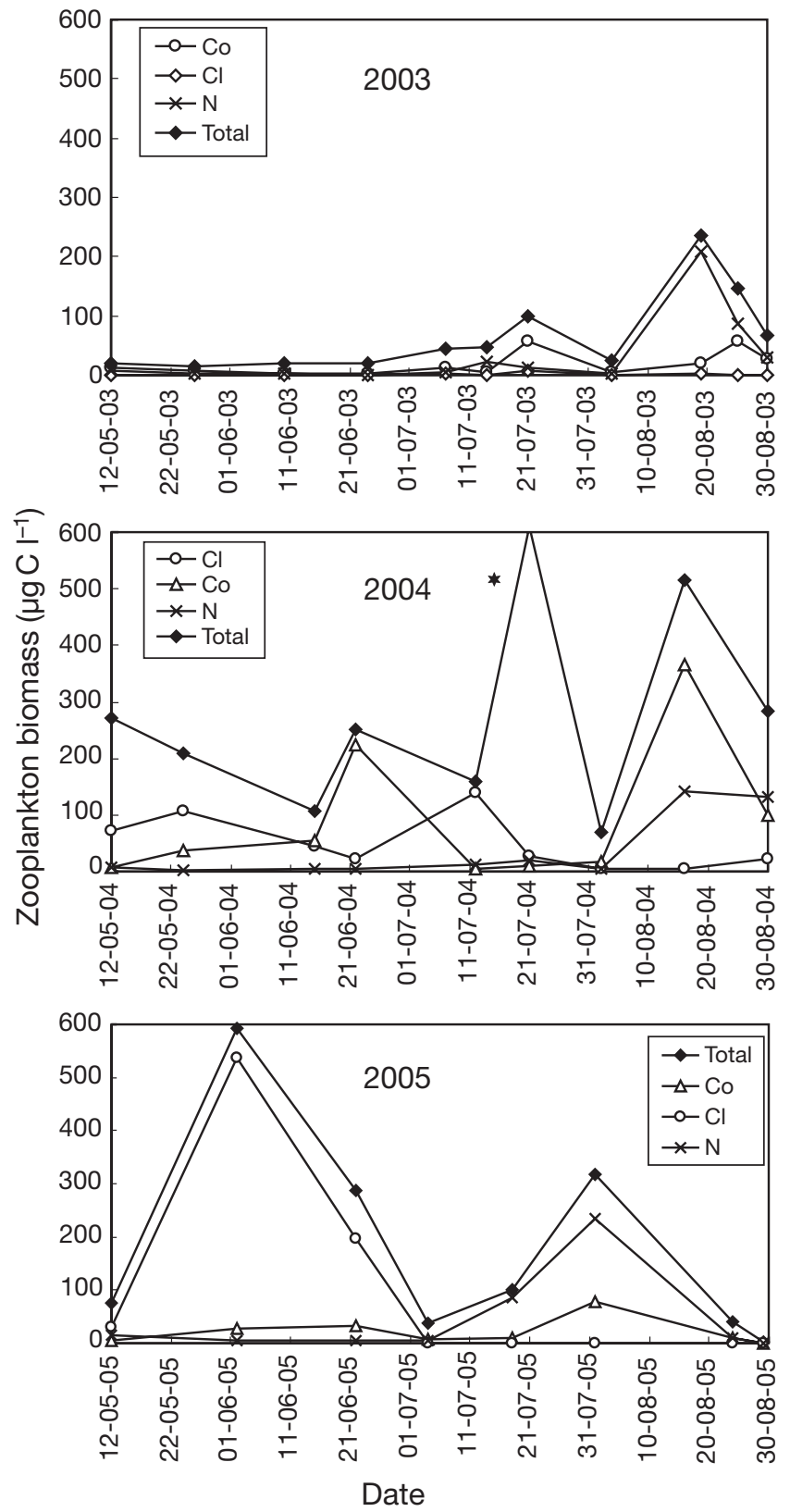

Fig. 6. Biomass and composition of dominant meso-zooplankton species in Skive Fjord in 2003, 2004, and 2005. N: copepod nauplii; Cl: cladocerans; Co: copepods. ${ }^{*}$ in (2004) indicates peak with a total biomass of $1300 \mu \mathrm{gC} \mathrm{l}^{-1}$ (mainly polychaete larvae) (dates are dd-mm-yy)

In Nissum Bredning (Fig. 7A) a stable biomass of meso-zooplankton was recorded during summer (about $100 \mu \mathrm{C} \mathrm{Cl}^{-1}$ ), consisting of both copepods, nauplii and cladocerans. The total meso-zooplankton biomass (mainly nauplii) increased to $200 \mu \mathrm{g} \mathrm{C} \mathrm{l}^{-1}$ in August. In Løgstør Bredning (Fig. 7B) copepods, cladocerans and nauplii were present in late May (100 to $150 \mu \mathrm{C} \mathrm{Cl}^{-1}$ ). Subsequently, the biomass of all species declined to almost zero in mid June. From July through

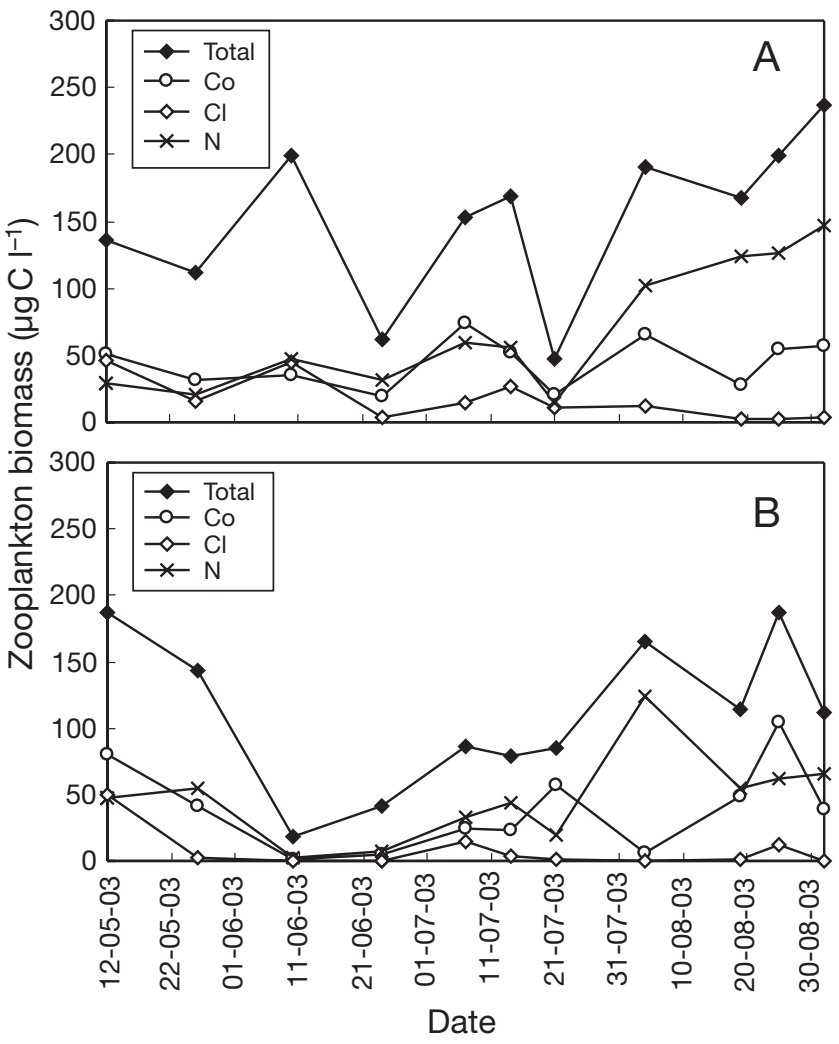

Fig. 7. Biomass and composition of dominant zooplankton species in (A) Nissum Bredning and (B) Løgstør Bredning in 2003. N: copepod nauplii; $\mathrm{Cl}$ : cladocerans; Co: copepods (dates are dd-mm-yy)

the rest of the summer, some adult copepods were present (up to $50 \mu \mathrm{g} \mathrm{Cl}^{-1}$ ), but the total meso-zooplankton was dominated by nauplii (50 to $100 \mu \mathrm{g} \mathrm{C} \mathrm{l}^{-1}$ ).

\section{Fish eggs and larvae}

In 2003, hauls were to estimate the number of fish eggs and larvae (Fig. 8). In Skive Fjord almost no eggs and larvae were found. The maximum concentrations recorded were 3 and 0.4 ind. $\mathrm{m}^{-3}$ eggs and larvae, respectively. The larvae present were herring Clupea harengus and gobies Gobiidae sp. More eggs and larvae were found in Løgstør Bredning (up to about 8 and 3 ind. $\mathrm{m}^{-3}$, respectively, in the period mid March to mid June). The larvae present were primarily $C$. harengus, Gobiidae sp., gunnels Pholis gunnellus, short-spined sea scorpion Myxocephalus scorpius and sand eels Hyperoplus sp. The highest abundance and diversity were found in Nissum Bredning. In the period mid April to the end of June, up to 25 eggs $\mathrm{m}^{-3}$ were found. Larvae were present from mid April to the end of June, when the concentration reached a maximum of 9 larvae $\mathrm{m}^{-3}$. In addition to the species above, sprat 

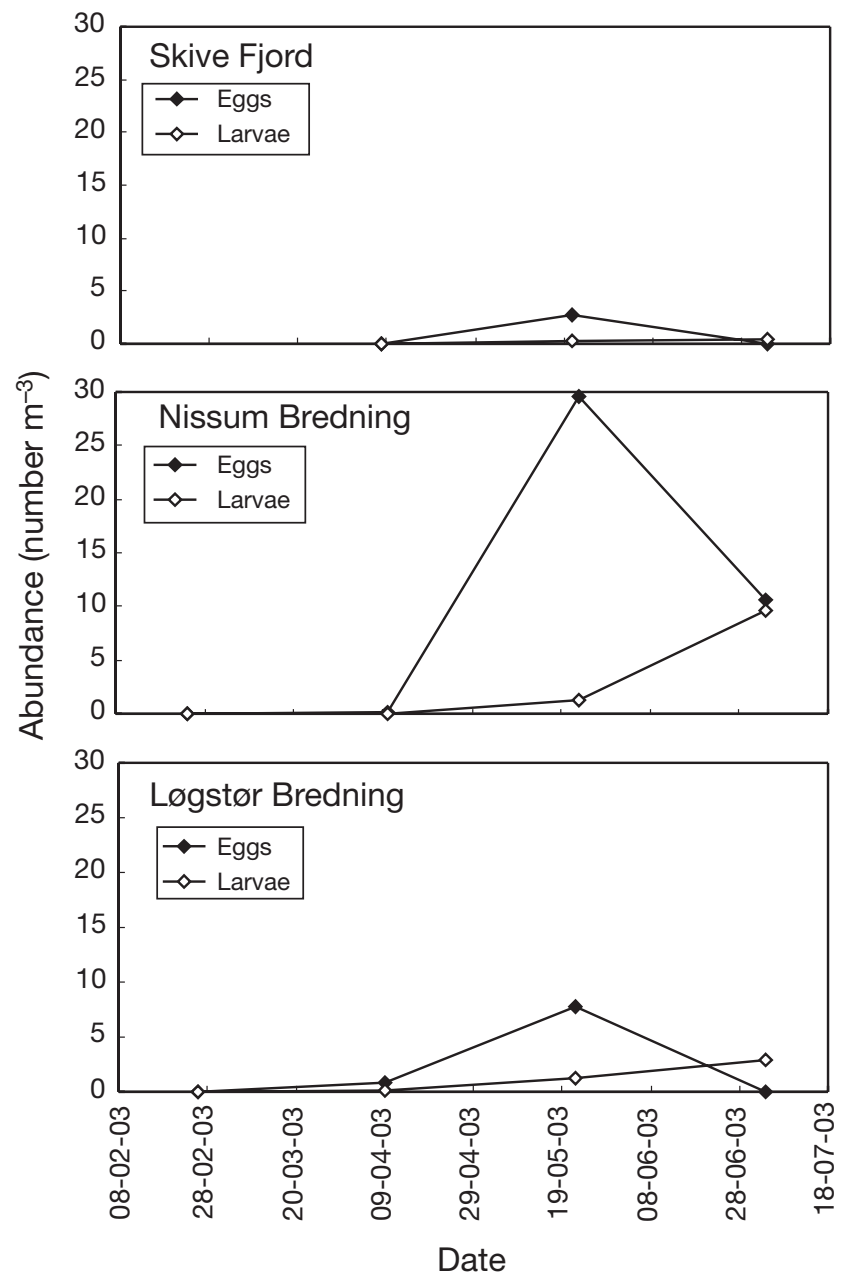

Fig. 8. Abundance of fish eggs and larvae in Skive Fjord (Fig. 1, location D), Nissum Bredning (location B), and Løgstør Bredning (location C) in 2003 (dates are dd-mm-yy)

Sprattus sprattus, flounder Platichthys flesus, pipefish Sygnathidae, and common sole Solea solea were among the dominant fish species in Skive Fjord.

In 2004 and 2005 there was no special sampling for eggs and larvae, but in all 3 yr the Limfjord County Authorities estimated their biomass $\left(\mathrm{\mu g} \mathrm{Cl}^{-1}\right)$ from weekly zooplankton sampling, giving a relative index of changes in biomass from year to year (Fig. 9). In 2003 no eggs were found, and larvae were present only at the beginning of July $\left(0.2 \mu \mathrm{g} \mathrm{C}^{-1}\right)$. In 2004, eggs were present from mid June to the end of July in concentrations up to $3 \mu \mathrm{g} \mathrm{C} \mathrm{l}^{-1}$. Larvae were present from late June, reaching a maximum concentration of $3 \mu \mathrm{C} \mathrm{Cl}^{-1}$ at the end of July. In 2005 eggs were present from early May $\left(1 \mu \mathrm{g} \mathrm{C}{ }^{-1}\right)$, reaching a maximum of $7 \mu \mathrm{g} \mathrm{Cl}^{-1}$ in early June, after which the concentration rapidly decreased to zero at the beginning of July. Larvae were present from early May, peaking in early June $(2 \mu \mathrm{g} \mathrm{C}$ $\mathrm{l}^{-1}$ ) and decreasing until the beginning of July.
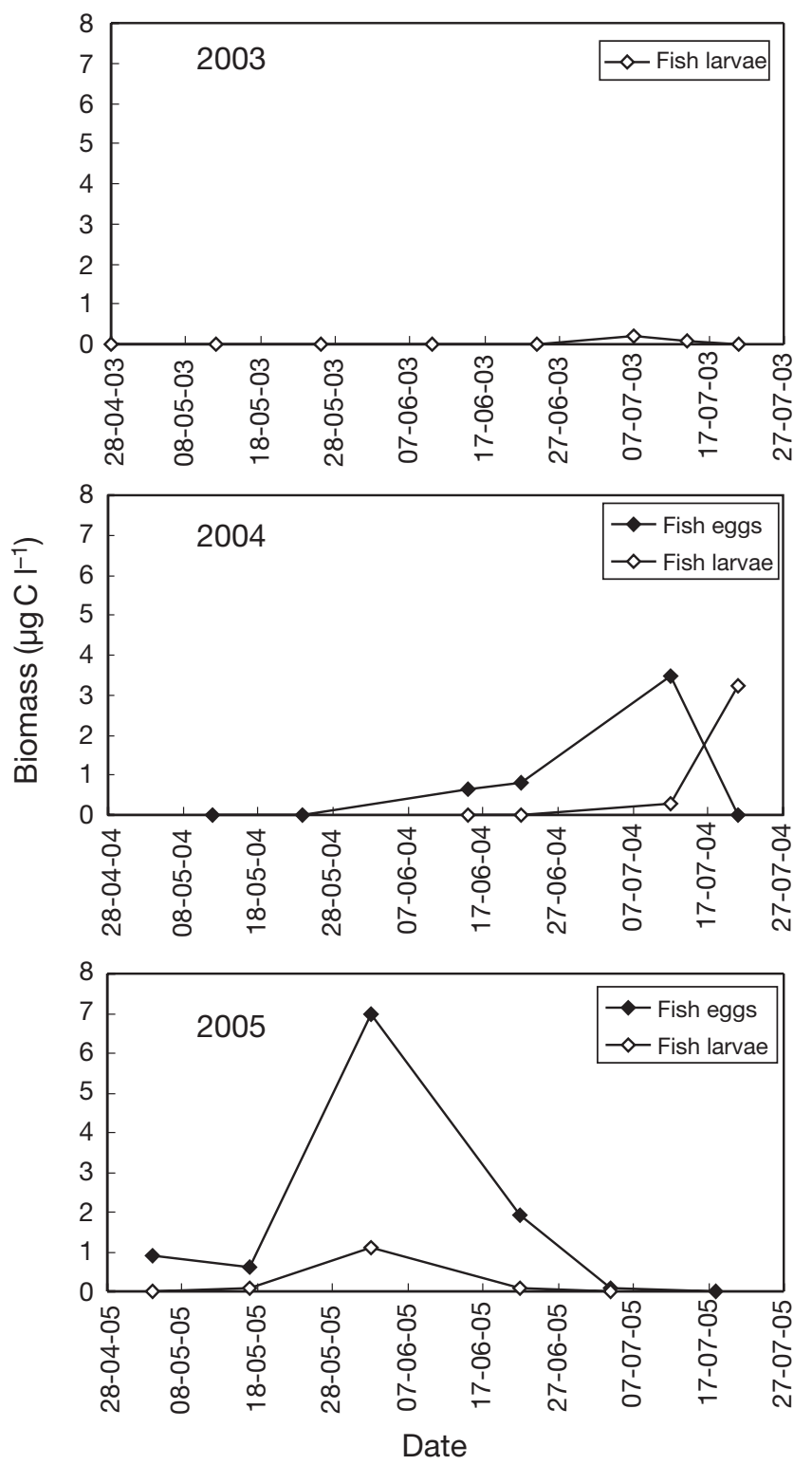

Fig. 9. Biomass of fish eggs and larvae in Skive Fjord in 2003, 2004, and 2005 (recorded in zooplankton samples collected by the Limfjord County Authorities) (dates are dd-mm-yy)

\section{DISCUSSION}

\section{Population dynamics}

The dynamics of Aurelia aurita and hydromedusae at 12 localities in Limfjorden in 2003 were described by Hansson et al. (2005) who found that Skive Fjord was one of the sites with highest biomass of this species. Accordingly, we chose Skive Fjord for more intensive studies during the following 2 years. In the early spring of 2004 and 2005, A. aurita ephyrae and hydromedusae were present in Skive Fjord, but they all disappeared in April/May. However, in August 2004 a new 
species, Aequorea vitrina, became abundant (Fig. 2). In addition to $A$. vitrina, which was also rather abundant in late summer 2005 (Fig. 4), the other species present in 2004 and 2005 were similar to those found in 2003, when Sarsia tubulosa, Rathkea octopunctata and Obelia sp. were dominant during spring (Hansson et al. 2005). In 2005, the small hydromedusae were also found during summer, with Leuckartiara octona, S. gemmifera and Lizzia blondina being the dominant species, although not in high concentrations. This corresponds to previous records by Blanner (1982).

Usually, the salinity in Limfjorden is slightly higher at the bottom than at the surface (Hansson et al. 2005), but this was not the case in either 2004 or 2005, when dramatic changes in the salinity levels and vertical profiles (Fig. 3) coincided with rapid disappearance and re-introduction of jellyfish. Thus, infrequent influxes of large volumes of highly saline seawater from the North Sea via Thyborøn Kanal may radically change hydrographic conditions and thereby strongly influence the distribution and abundance of jellyfish in Limfjorden. This phenomenon makes a straightforward interpretation of the data on population densities and actual specific growth rates of jellyfish from 2004 and 2005 somewhat difficult, and it underlines the necessity of including hydrodynamic factors for a satisfactory understanding the population dynamics of jellyfish in this fjord (which is actually a sound, with an opening to the highly saline North Sea in west and another to the more brackish Kattegat in east). However, to deal with the above uncertainties in the present study, we calculated actual specific growth rates only in those cases when the salinity profiles measured on 2 sampling dates were similar, indicating that the jellyfish were sampled from the same population.

The influence of varying hydrodynamic conditions on the interaction between Aurelia aurita and zooplankton, and hence the phytoplankton, were studied in the Kertinge Nor (northern part of Fyn, Denmark) by Nielsen et al. (1997). The local population of jellyfish was highly influenced by density-driven circulation created by frequent salinity changes in the adjacent Great Belt. When new water entered the fjord (either higher or lower salinity), changes in the jellyfish distribution were apparent. The time it took for the jellyfish to enter a new water mass of higher or lower salinity was found to be dependent on the degree of changes in salinity. Further, the number and distribution of zooplankton was found to be highly influenced by the presence of jellyfish. The disappearance of incoming copepods from the Great Belt occurred concurrently with the burgeoning of the jellyfish population in the new water mass. Obviously, similar conditions with density-driven currents may be important for understanding the population dynamics of jellyfish and their predation impact in Limfjorden, which, in addition to incoming North Sea water via Thyborøn Kanal, also receives a high input of freshwater from the surrounding, mainly agricultural, land area, resulting in a salinity gradient from west to east (Jørgensen 1980)

\section{Growth and predation impact}

Hansson et al. (2005) found that the predation of Aurita aurita ephyrae and the hydromedusae was of minor importance during spring 2003, and since their abundance was even lower in 2004 and 2005, this aspect has not been considered in the present study. Although not important in relation to predation potential, the present work provides information on growth and prey selection for $A$. aurita ephyrae and Sarsia tubulosa. In 2004 and 2005, specific growth rates were obtained for ephyrae and $S$. tubulosa during spring (Table 3). Maximum specific growth rates $\left(0.05 \mathrm{~d}^{-1}\right)$ were achieved in certain periods, but the actual growth rate varied conspicuously, probably due to strobilation of new individuals. The main prey item for S. tubulosa is believed to be copepods (Daan 1986), but the species can also feed on copepod nauplii (Møller \& Riisgård 2007) and cirriped larvae (Hansson \& Kiørboe 2006). Ephyrae are known to prey and grow on a variety of prey types, including cirriped larvae (Møller \& Riisgård 2007). The main prey item for both A. aurita ephyrae and $S$. tubulosa was probably cirriped larvae in both 2004 and 2005, since almost no other prey items were present in sufficiently high concentrations to account for the observed growth rates (Møller \& Riisgård 2007).

In 2003, when Aurelia aurita was present during the entire study period (February to August), we measure the actual specific growth rate at 12 sampling localities throughout the year (Table 1). Because the growth pattern was similar at all sampling localities, it can be assumed that we sampled the same population from week to week. The trend with low growth rates during winter, higher rates during spring, then lower again during summer, and finally negative growth in August is a pattern that has been observed previously at several study sites, e.g. Kiel Bight (Möller 1980) and Vågsbøpollen, Norway (Ishii \& Båmstedt 1998). By estimating specific growth rates from the data reported by Möller (1980), we calculated $0.05 \mathrm{~d}^{-1}$ for spring, $0.15 \mathrm{~d}^{-1}$ for early June, and 0.03 to $0.05 \mathrm{~d}^{-1}$ for summer, and then negative growth in September, i.e. a pattern comparable to that in Limfjorden (Table 1).

Patterns of growth and maximum bell diameter may, however, vary considerably among different Aurelia aurita populations (Lucas 2001). In more open areas, 
the individuals often reach bell diameters of 20 to $30 \mathrm{~cm}$ (Möller 1980, Schneider \& Behrends 1994). In some localities, however, natural populations of A. aurita can be severely food-limited. Thus, in the shallow cove of Kertinge Nor, the maximum diameter of the umbrella is usually only 3 to $4 \mathrm{~cm}$, although high abundances of such small jellyfish (up to 300 ind. $\mathrm{m}^{-3}$ ) control the zooplankton biomass (Olesen et al. 1994, Riisgård et al. 1995, Frandsen \& Riisgård 1997). A similar situation has been described for Horsea Lake, England (Lucas \& Lawes 1998).

To evaluate whether the jellyfish in Limfjorden realised their growth potential, or whether they were food-limited in the study period, the actual specific growth rates in the field $\left(\mu_{\text {act }}\right)$ may be compared to the maximum specific growth rates obtained in controlled laboratory experiments ( $\mu_{\max }$ ) (Møller \& Riisgård 2007). As discussed by Møller \& Riisgård (2007), the maximum specific growth rate decreases with increasing medusa size. In the present study, the relation used (estimated from data obtained by Ishii \& Båmstedt 1998, and assumed in the present work to be valid also for larger individuals) was $\mu_{\max }=0.34 W^{-0.28}$. When correcting for the ambient temperature, we estimate that Aurelia aurita realised its growth potential in Limfjorden in 2003 from April until August, after which negative growth was observed. In 2004, data were only available in late summer, and the growth potential was realised in August, followed by negative growth.

It has been suggested that negative growth may be due to lack of food, infection by the parasite Hyperia galba, or genetic programming (Möller 1980). H. galba was found in up $80 \%$ of the A. aurita population in July and August 2003, and this parasite could have caused the negative growth. However, by comparing the minimum concentration of a specific prey organism $\left(C_{\min }\right)$ needed to sustain maximum growth with the actual prey concentrations in the field, we can estimate whether the observed negative growth is likely to have been caused by lack of food. From laboratory experiments, Møller \& Riisgård (2007) found that $C_{\min }$ was about $100 \mu \mathrm{g} \mathrm{C}^{-1}$ for Aurelia aurita preying on the copepod Acartia tonsa. Since the biomass of zooplankton in August was generally higher than $100 \mu \mathrm{g} \mathrm{C}^{-1}$, food was apparently available in superfluity. However, the zooplankton biomass consisted mainly of nauplii, and several studies indicate that the clearance of nauplii is considerably lower than that of copepods (Hansson et al. 2005, Hansson 2006), and because this will increase the estimated $C_{\min }$, the actual prey concentration may not have been sufficiently high to sustain maximum growth.

When comparing data for Skive Fjord in 2003 with those for 2004 and 2005, the predation effect of jellyfish can be assessed during summer, since almost no
Aurelia aurita were present until August in 2004 and 2005. In the present study, half life times $\left(t_{1 / 2}\right)$ have been calculated for Acartia tonsa, which was the prey organism used for constructing carbon budgets for jellyfish (Møller \& Riisgård 2007). In 2003, A. aurita had a high potential $\left(t_{1 / 2}=1\right.$ to $\left.6 \mathrm{~d}\right)$ for preying on $A$. tonsa from mid May to August in Skive Fjord (Table 2). According to Hansson et al. (2005) and Hansson (2006), clearance of cladocerans is even higher than for copepods, and almost none of the 2 prey organisms appeared in Limfjorden from the end of May to the beginning of July 2003. Both copepods and cladocerans were present in high concentrations during the summer of 2004, when no A. aurita were present, and in 2005 where cladocerans were present in concentrations up to $600 \mu \mathrm{g} \mathrm{C}^{-1}$ (Fig. 6). In Nissum Bredning, the half-life times (Table 2) were relatively high through most of the summer, during which the biomass of zooplankton (consisting mainly of copepods, nauplii and cladocerans; Fig 7A) was rather stable (about $100 \mu \mathrm{g} \mathrm{C}^{-1}$ ). In Løgstør Bredning, the half-life time was high $\left(t_{1 / 2}=26 \mathrm{~d}\right)$ in late May when copepods, cladocerans and nauplii were present in a combined total concentration of 100 to $150 \mu \mathrm{g} \mathrm{C}^{-1}$. Subsequently, the half-life times decreased to 6 to $11 \mathrm{~d}$ during the rest of the summer, coinciding with the absence of adult copepods and cladocerans during June. From July, adult copepods were present (up to $50 \mu \mathrm{g} \mathrm{C}^{-1}$ ), but the total zooplankton was dominated by nauplii (up to $100 \mu \mathrm{g} \mathrm{C}^{-1}$ ).

In the 3 years of the study, a large number of nauplii appeared in August in response to increased chl a concentrations caused by nutrient release from the bottom during events of severe oxygen depletion (Fig. 5). In 2003, however, the nauplii did not develop into adults, probably because Aurelia aurita exerted a very high predation pressure. In 2004, the nauplii developed to adult copepods, likely because the predation impact exerted by A. aurita was insufficient to control the zooplankton. In 2005, the ctenophore Pleurobrachia sp. was very abundant at the end of the summer, and presumably responsible for low copepod concentrations at that time.

Copepods and cladocerans are suggested to be some of the primary prey items of Aurelia aurita. Barz \& Hirche (2005) found that cladocerans were the dominant food items in the gut of $A$. aurita during summer in the Bornholm Basin. In the Black Sea, Mutlu (2001) found that $A$. aurita preyed primarily on copepods and bivalve larvae, and to some extent on fish eggs and larvae, while Martinussen \& Båmstedt (1995) found that bivalve larvae and cladocerans dominated the food of A. aurita in Raunefjorden, Norway.

The present study indicates that during summer Aurelia aurita may also prey heavily on prey types 
other than meso-zooplankton. A. aurita realised its growth potential during the summer of 2003, although the zooplankton biomasses recorded at the 3 localities were not sufficiently high to sustain the actual observed growth. In Skive Fjord, almost no mesozooplankton was present in June (Fig. 6). An explanation may be that $A$. aurita fed on prey organisms that we have not considered. Fish eggs and larvae may have supplemented the food for a short period, but they were not abundant enough to sustain the observed growth of $A$. aurita. A few studies have suggested that micro-zooplankton, e.g. ciliates may be prey items for A. aurita (Stoecker et al. 1987, Båmstedt 1990, Olesen 1995), but little is known about the role of ciliates in the diet of $A$. aurita.

The function of Aurita aurita as a local key organism may manifest itself not only as great variations in zooplankton, but also in the abundance of phytoplankton communities. Release of phytoplankton from zooplankton grazing control (due to top-down predation pressure by A. aurelia on zooplankton) may trigger, or reinforce phytoplankton blooms. Thus, in Skive Fjord, oxygen depletion triggered nutrient release from the sediment in each year of the project (in July to August), but in only 2003 (when the zooplankton was controlled by $A$. aurita) did this lead to a pronounced algal bloom

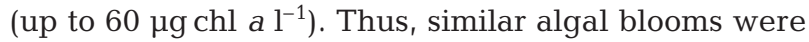
not observed in 2004 and 2005, when A. aurita was absent, and although the primary production was equally high (Fig. 5).

The hydromedusa Aequorea vitrina is a new species in Limfjorden, occurring in high abundances for the first time in August to September 2004. To our knowledge, no previous records exist on specific growth rates of Aequorea sp. in the field. Laboratory feeding experiments made by Møller \& Riisgård (2007) indicate that $A$. vitrina was growing at maximum specific growth rates in Limfjorden during late August and early September (Table 5). Copepods and nauplii were the only zooplankton species present in this period, but from the estimated half-life times for copepods ( $>54 \mathrm{~d}$ ), it is clear that $A$. vitrina had no predatory effect on the copepod biomass. However, as pointed out by Møller \& Riisgård (2007), the predation impact by $A$. vitrina on soft-bodied prey may be several times higher than on zooplankton, thus indicating that this cnidarian population in Skive Fjord could have exerted control on soft-bodied prey, such as the ctenophore Pleurobrachia sp. Arai (1980) showed that A. victoria is able to grow on Pleurobrachia sp., however no data on predation rates exist. In Skive Fjord, Pleurobrachia sp. disappeared in the period when A. vitrina was growing (L. F. Møller unpubl. obs.), and therefore this ctenophore may have been the primary prey item.

\section{Effect on fish larvae}

Hansson et al. (2005) reported that Aurelia aurita may have had a severe impact on fish larvae in Limfjorden during late spring and summer 2003, and this statement is supported by the present study. Titelman \& Hansson (2006) estimated clearance of cod larvae by A. aurita, and they reviewed the existing literature on predation on fish larvae. In general, it was found that the predation on fish larvae is higher than that on zooplankton, implying that $A$. aurita in Skive Fjord and Løgstør Bredning may have had the potential in 2003 to control the abundance of fish larvae from early May, but only during mid-summer in Nissum Bredning. Only few fish larvae of Clupea sp. and Gobidae sp. were present in Skive Fjord in 2004 (Fig. 8). By comparing Skive Fjord with Nissum Bredning and Løgstør Bredning, a negative relation between abundance of A. aurita and abundance of eggs and larvae is indicated (Fig. 8). Although the the 3 yr data set for fish eggs and larvae in Skive Fjord may be underestimates (because no specific samplings for fish eggs and larvae were made) it is striking that almost no fish eggs and larvae were found in 2003 when A. aurita was abundant in the fjord, whereas higher concentrations were recorded in 2004 and 2005 when A. aurita was absent (Fig. 9).

\section{CONCLUSION}

In certain years, Aurelia aurita may be very abundant in Limfjorden, and during the summer period it may exert a considerable predatory impact on a broad spectrum of zooplankton species and fish larvae. The abundance, species composition and population dynamics of jellyfish in Limfjorden may be strongly influenced at times by dramatic, but apparently rather unusual hydrographic events, and hydraulic processes may explain otherwise unaccountably large variations in the plankton (including jellyfish) composition and biomass. The jellyfish predatory impact and its structuring effects on the planktonic communities in Limfjorden is not yet completely clear, but zooplankton (and fish larvae) and phytoplankton biomasses may be severely affected by mass occurrence of $A$. aurita, as observed in 2003 when $A$. aurita realised its growth potential, although the concentration of zooplankton recorded was not sufficiently high to sustain the observed growth, implying that $A$. aurita may also feed on prey types not considered in the present study.

Acknowledgements. This work formed part of the EUROGEL project (EVK3-CT-2002-00074). Thanks are due to the Limfjord County Authorities (Limfjordsamterne) for excellent co- 
operation, and to G. Pedersen and B. Jensen on RV 'Limgrim' for valuable help. We highly appreciate the constructive criticism made by 4 reviewers, in particular by J. E. Purcell, who revealed her identity.

\section{LITERATURE CITED}

Andersen JH, Markager SS, Ærtebjerg G (2004) Tekniske anvisninger for marin overvågning. NOVANA, Danmarks Miljøundersøgelser (in Danish)

Arai MN (1980) Growth rates of Aequorea medusae. In: Tardent $\mathrm{P}$, Tardent R (eds) Developmental and cellular biology of coelenterates. Elsevier Biomedical Press, Amsterdam, p 163-168

Båmstedt U (1990) Trophodynamics of the scyphomedusae Aurelia aurita. Predation rate in relation to abundance, size and type of prey organism. J Plankton Res 12:125-229

Båmstedt U, Lane J, Martinussen MB (1999) Bioenergetics of ephyra larvae of the scyphozoan jellyfish Aurelia aurita in relation to temperature and salinity. Mar Biol 135:89-98

Barz K, Hirche HJ (2005) Seasonal development of scyphozoan medusae and the predatory impact of Aurelia aurita on the zooplankton community in the Bornholm Basin (central Baltic Sea). Mar Biol 147:465-476

Behrends G, Schneider G (1995) Impact of Aurelia aurita medusae (Cnidaria, Schyphozoa) on the standing stock and community composition of mezozooplankton in the Kiel Bight (western Baltic Sea). Mar Ecol Prog Ser 127:39-45

Blanner P (1982) Composition and seasonal variation of the zooplankton in the Limfjord (Denmark) during 1973-1974. Ophelia 21:1-40

Daan R (1986) Food intake and growth of Sarsia tubulosa (Sars, 1835) with quantitative estimates of predation on copepod populations. Neth J Sea Res 20:67-74

Frandsen KT, Riisgård HU (1997) Size dependent respiration and growth in jellyfish Aurelia aurita. Sarsia 82:307-312

Gibbons MJ, Painting SJ (1992). The effects and implications of container volume on clearance rates of the ambush entangling predator Pleurobrachia pileus (Ctenophora: Tentaculata). J Exp Mar Biol Ecol 163:199-208

Hansson LJ (2006) A method for in situ estimation of prey selectivity and predation rate in large plankton, exemplified with the jellyfish Aurelia aurita (L.). J Exp Mar Biol Ecol 326: 113-126

Hansson LJ, Kiørboe T (2006) Prey-specific encounter rates and handling efficiencies as causes of prey selectivity in ambush-feeding hydromedusae. Limnol Oceanogr 51: 1849-1858

Hansson LJ, Moeslund O, Kiørboe T, Riisgård HU (2005) Clearance rates of jellyfish and their potential predation impact on zooplankton and fish larvae in a neritic ecosystem (Limfjorden, Denmark). Mar Ecol Prog Ser 304:117-131

Hoffmann E, Dolmer P (2000) Effects of closed areas on distribution of fish and epibenthos. ICES J Mar Sci 57: 1310-1314

Ishii H, Båmstedt U (1998) Food regulation of growth and maturation in a natural population of Aurelia aurita (L.). J Plankton Res 20:805-816

Jørgensen BB (1980) Seasonal oxygen depletion in the bottom waters of a Danish fjord and its effect on the benthic community. Oikos 34:68-76

Lucas CH (2001) Reproduction and life history strategies of the common jellyfish, Aurelia aurita, in relation to its ambient environment. Hydrobiologia 451:229-246

Lucas CH, Lawes S (1998) Sexual reproduction of the scypho-
Editorial responsibility: Howard Browman (Associate Editorin-Chief), Storebø, Norway medusa Aurelia aurita (L.) in relation to temperature and variable food supply. Mar Biol 131:629-638

Lynam CP, Heath MR, Hay SJ, Brierly AS (2005) Evidence for impacts by jellyfish on North Sea herring recruitment. Mar Ecol Prog Ser 298:157-167

Martinussen MB, Båmstedt U (1995) Diet, estimated daily food ration and predator impact by the scyphozoan jellyfishes Aurelia aurita and Cyanea capillata. In: Skjoldahl HR, Hopkins C, Erikstad KE, Leinaas HP (eds) Ecology of fjords and coastal waters. Elsevier Science Publishers, Amsterdam, p 127-145

Möller H (1980) Population dynamics of Aurelia aurita medusae in Kiel Bight, Germany (FRG). Mar Biol 60: $123-128$

Möller H (1984) Reduction of larval herring populations by jellyfish predation. Science 224:621-622

Møller LF, Riisgård HU (2007) Feeding, bioenergetics and growth in the common jellyfish Aurelia aurita and two hydromedusae, Sarsia tubulosa and Aequorea vitrina. Mar Ecol Prog Ser 346:167-177

Mutlu E (2001) Distribution and abundance of moon jelly fish (Aurelia aurita) and its zooplankton food in the Black Sea. Mar Biol 138:329-339

Nielsen AS, Pedersen AW, Riisgård HU (1997) Implications of density driven currents for interaction between jellyfish (Aurelia aurita) and zooplankton in a Danish fjord. Sarsia 82:297-305

Olesen NJ (1995) Clearance potential of jellyfish Aurelia aurita, and predation impact on zooplankton in a shallow cove. Mar Ecol Prog Ser 124:63-72

Olesen NJ, Frandsen K, Riisgård HU (1994) Population dynamics, growth and energetics of jellyfish Aurelia aurita in a shallow fjord. Mar Ecol Prog Ser 105:9-18

Purcell JE (1997) Pelagic cnidarians and ctenophores as predators: selective predation, feeding rates, and effects on prey populations. Ann Inst Oceanogr Paris 73:125-137

Purcell JE, Grover JJ (1990) Predation and food limitation as causes of mortality in larval herring at a spawning ground in British Columbia. Mar Ecol Prog Ser 59:55-61

Riisgård HU (2007) Feeding behaviour of the hydromedusa Aequorea vitrina. Sci Mar 71:395-404

Riisgård HU, Poulsen E (1981) Growth of Mytilus edulis in net bags transferred to different localities in a eutrophicated Danish fjord. Mar Pollut Bull 12:272-276

Riisgård HU, Christensen PB, Olesen NJ, Petersen JK, Møller MM, Andersen P (1995) Biological structure in a shallow cove (Kertinge Nor, Denmark): control by benthic nutrient fluxes and suspension-feeding ascidians and jellyfish. Ophelia 41:329-344

Schneider G (1988) Chemische Zusammensetzung und Biomasseparameter der Ohrenqualle Aurelia aurita. Helgol Meeresunters 42:319-327

Schneider G, Behrends G (1994) Population dynamics and the trophic role of Aurelia aurita medusae in the Kiel Bight and western Baltic. ICES J Mar Sci 51:359-367

Stoecker DK, Michaels AE, Davis LH (1987) Grazing by the jelllyfish, Aurelia aurita, on microzooplankton. J Plankton Res 9(5):901-915

Svendsen LM, Norup B (2005) NOVANA. Nationwide monitoring and assessment programme for the aquatic and terrestrial environments. Programme description. Part 1. Tech Rep No. 532. National Environmental Research Institute, Ministry of the Environment, Copenhagen

Titelman J, Hansson LJ (2006) Feeding rates of the jellyfish Aurelia aurita on fish larvae. Mar Biol 149:297-306

Submitted: September 8, 2006; Accepted: March 3, 2007

Proofs received from author(s): September 10, 2007 